DOI: https://doi.org/10.32838/2523-4803/69-5-27

УДК 338.24

\title{
Богуславська C.I.
}

кандидат економічних наук, доцент,

доцент кафедри менеджменту та економічної безпеки,

Черкаський національний університет імені Богдана Хмельницького

Овсюк Н.В.

доктор економічних наук,

доцент кафедри економіки, підприємництва та природничих наук,

Таврійський національний університет імені В.І. Вернадського

\section{Boguslavska Svitlana}

Bohdan Khmelnytsjyi National University of Cherkasy

Ovsyuk Nina

Taurida National V.I. Vernadsky University

\section{СТРАТЕГІЯ РЕСУРСНОГО ЗАБЕЗПЕЧЕННЯ СТАЛОГО РОЗВИТКУ РЕГІОНУ}

Досягнення стійкості і комплексності передбачає вдосконалення системи ресурсного забезпечення розвитку території на основі стратегічного планування, використання сучасних технологій управління регіональною системою ресурсного забезпечення, впровадження системи ї̈ ефективності. $У$ статті визначено зміст стратегії ресурсного забезпечення, щз включає кілька елементів, орієнтованих на зовнішню і внутрішню сфери життєдіяльності на регіональному рівні; сформульовані завдання і приниципи стратегічного планування ресурсного забезпечення; визначений ичикл його формування і реалізації. Сформульовано основні напрямки стратегії ресурсного забезпечення, щзо базується на самовідтворення ресурсів і передбачає активні дії з саморозвитку економіки і організаційно-економічних відносин 8 регіонах. Охарактеризована стратегія ресурсного забезпечення сталого розвитку регіону, яка містить самостійні ресурсні компоненти, реалізовані в його зовнішньому і внутрішньому середовищі.

Ключові слова: регіон, сталий розвиток, ресурсне забезпечення, стратегія, стратегічне управління.

Постановка проблеми. Рівень і якість життя населення, екологічне благополуччя, структура і стан економіки, функціонування і розвиток регіонів України, значно відрізняються один від одного.

3 початку 90-х років минулого століття реформування господарства проводилося на основі поляризованого розвитку, яке поряд 3 досягнутими соціально-економічними цілями, призвело до посилення диспропорцій в ресурсному забезпеченні, функціонуванні економіки і територій, в рівні і якості життя населення. У зв'язку з цим, назріла необхідність у зміні підходів і моделей регіонального розвитку.

Аналіз останніх досліджень та публікацій. Багато аспектів ресурсного підходу до управління дослідженні в роботах таких вчених: I.В. Бакум, I. В. Бережна, М.С. Бернер., А. В. Євдокимов, О. О. Євсєєва, Ш. І. Ібатуллін, Я. В. Коваль, Л. В. Левковська, Л. О. Петкова, 3. С. Варналій, Я. Б. Олійник, В. Ф. Столяров.

Постановка завдання. Обгрунтувати і сформулювати критерії стратегії ресурсного забезпечення сталого розвитку регіону.

Виклад основного матеріалу дослідження. Досягнення стійкості і комплексності передбачає вдосконалення системи ресурсного забезпечення розвитку регіонів на основі стратегічного планування. На думку багатьох авторів, воно є на даному етапі найбільш дієвими інструментом управління розвитком економічних агентів різних рівнів. Практика довела високу ефективність, а в ряді випадків нагальну необхідність застосування стратегічного планування в різних сферах і видах людської діяльності [4].

Існують різні визначення понять «стратегія», «стратегічне управління», «стратегія розвитку». Так, А.А. Томпсон і А. Дж. Стрікленд вважають, що в загальному сенсі стратегія - це план управління фірмою, спрямований на зміцнення іiі позицій, задоволення потреб і досягнення поставлених цілей [4]. На думку Кунца «стратегія - це генеральна програма дій, що виявляє пріоритети проблем і ресурси для досягнення основної мети» [1]. Дж. Глін та інші вважають, що «стратегічне управління - це процес прийняття i здійснення стратегічних рішень, центральною ланкою якого $\epsilon$ стратегічний вибір, заснований на зіставленні власного ресурсного потенціалу підприємства 3 можливостями і загрозами зовнішнього оточення» [1].

Під стратегією ресурсного забезпечення сталого розвитку регіону автором розуміється комплекс довгострокових цілей, завдань і напрямів дій органів влади i економічних агентів по саморозвитку потенціалів на основі відтворення ресурсів, їх цільового, раціональ- 
ного і ефективного використання. Основою для розробки збалансованих між собою стратегій ресурсного забезпечення, $є$ стратегія регіонального розвитку держави, яка формує і генералізує основні цілі та завдання розвитку на конкретному часовому етапі.

Стратегія ресурсного забезпечення являє собою частину стратегічного плану сталого розвитку регіону, одного з основних нормативно-правових документів суспільного погодження, що розробляється і затверджується органами влади. Стратегічний план визначає ключові цілі співтовариства і покликаний об'єднувати його на основі гармонізації інтересів шляхом вибору пріоритетних завдань задоволення конфліктуючих потреб різних суб'єктів території. Він формує основні комплексні цільові програми, необхідні і достатні для переходу регіональної системи 3 одного стану розвитку в інше.

У зміст стратегії ресурсного забезпечення сталого розвитку включається декілька елементів (рис. 1), які орієнтовані на зовнішню і внутрішню сфери життєдіяльності. Це означає, що результати реалізації стратегії ресурсного забезпечення обумовлені, з одного боку, впливом цих сфер на характер прийнятих рішень, 3 іншого, впливом самих стратегічних рішень на процеси, що протікають у внутрішньому та зовнішньому середовищі регіону. Формування стратегії ресурсного забезпечення розвитку має здійснюватися з урахуванням наступних принципів стратегічного планування, орієнтованих на підвищення якості життєдіяльності [2]: 1) комплексності (взаємної адаптації цілей за конкретними напрямами); 2) ефективності формування, відтворення, розподілу і використання обмежених ресурсів; 3) реалістичності і можливості бути реалізованим стратегічного плану (співвіднесеності ресурсів з умовами проектованої діяльності та інтересами суб'єктів, що беруть участь в процесі планування та реалізації стратегіï); 4) відкритості процесу стратегічного планування для всіх зацікавлених сторін; 5) збалансованості соціо-еколого-економічних і соціо-культурних традицій та інновацій в розвитку регіональної системи; 6) узгодженості планування з регіональними та національними тенденціями соціально-економічного розвитку; 7) концентрації зусиль на найбільш перспективних напрямках розвитку.

В процесі розробки стратегії ресурсного забезпечення, на нашу думку, повинні вирішуватися наступні завдання:

1. Формування структурної схеми стратегії, яка визначає спрямованість і весь хід концептуального проектування розвитку регіону;

2. Дослідження закономірностей і прогнозування напрямків розвитку потенціалів регіонально й системи в рамках спроектованої схеми стратегії;

3. Визначення проблем і формування структури цілей регіонального розвитку у взаємозв'язку 3 ï ресурсним забезпеченням;

4. Опис проблем і формулювання цілей ресурсного забезпечення, оцінка їх відносної важливості (визначення пріоритетів);
5. Проектування сценаріїв розвитку регіону і його ресурсного забезпечення. Відзначимо, що процедури стратегічного планування, які використовуються на державному, регіональному і фірмовому рівні, при відповідній адаптації можуть застосовуватися до формування стратегії ресурсного забезпечення розвитку регіону.

Цикл розробки стратегії ресурсного забезпечення розвитку регіону включає кілька взаємопов'язаних дій:

1) формується група розробників і експертів, що включає представників органів місцевого самоврядуванн, місцевих підприємств і громадськості;

2) уточнюється місія регіону, виявляються і узгоджуються інтереси різних груп населення, бізнесу i влади;

3) проводиться комплексне дослідження функціонування регіону, яке включає:

a) системний аналіз зовнішнього середовища і прогноз очікуваних змін ближнього і далекого оточення регіону;

б) системний аналіз потенціалів розвитку на місцевому рівні і ресурсів, а також прогноз розвитку регіону;

4) формуються стратегічні ціннісні установки i завдання сталого розвитку на місцевому рівні, а також пріоритети, цілі і завдання стратегії ресурсного забезпечення його розвитку, взаємопов'язані з загальною стратегією регіону;

5) розробляється методика формування стратегії, визначаються методи аналізу і прогнозу, критерії та індикатори оцінки оптимальності і ефективності ресурсного забезпечення;

6) формується концепція і політика ресурсного забезпечення на 25-30 років, а також відповідний стратегічний план на 10-15 років, що включає всі структурні елементи стратегії ресурсного забезпечення;

7) розробляються контрастні (орієнтовані на одну із стратегічних цілей) сценарії майбутнього стану системи ресурсного забезпечення, складається комплексний сценарій розвитку системи ресурсного забезпечення, виділяються і обгрунтовуються основні пріоритети для органів місцевого самоврядування та інших суб'єктів муніципального освіти;

8) визначаються конкретні плани з реалізації стратегії на середньострокову перспективу: програми на 5-8 років і проекти на 1-3 роки, із зазначенням конкретних термінів і відповідальних за їх виконання.

9) безпосередньо організовується робота 3 реалізації стратегії ресурсного забезпечення розвитку регіону, в процесі якої узгоджуються і координуються дії суб'єктів регіональної системи;

10) проводиться регулярний моніторинг, діагностика ситуацій, проблем, а також результатів ресурсного забезпечення, 3 наданням інформації зацікавленим користувачам в ході реалізації стратегії, на підставі яких може коригуватися як сама стратегія, так і окремі плани, програми, підпрограми, проекти.

Сучасний етап розвитку більшості регіонів України характеризується недостатнім ресурсним забезпе- 


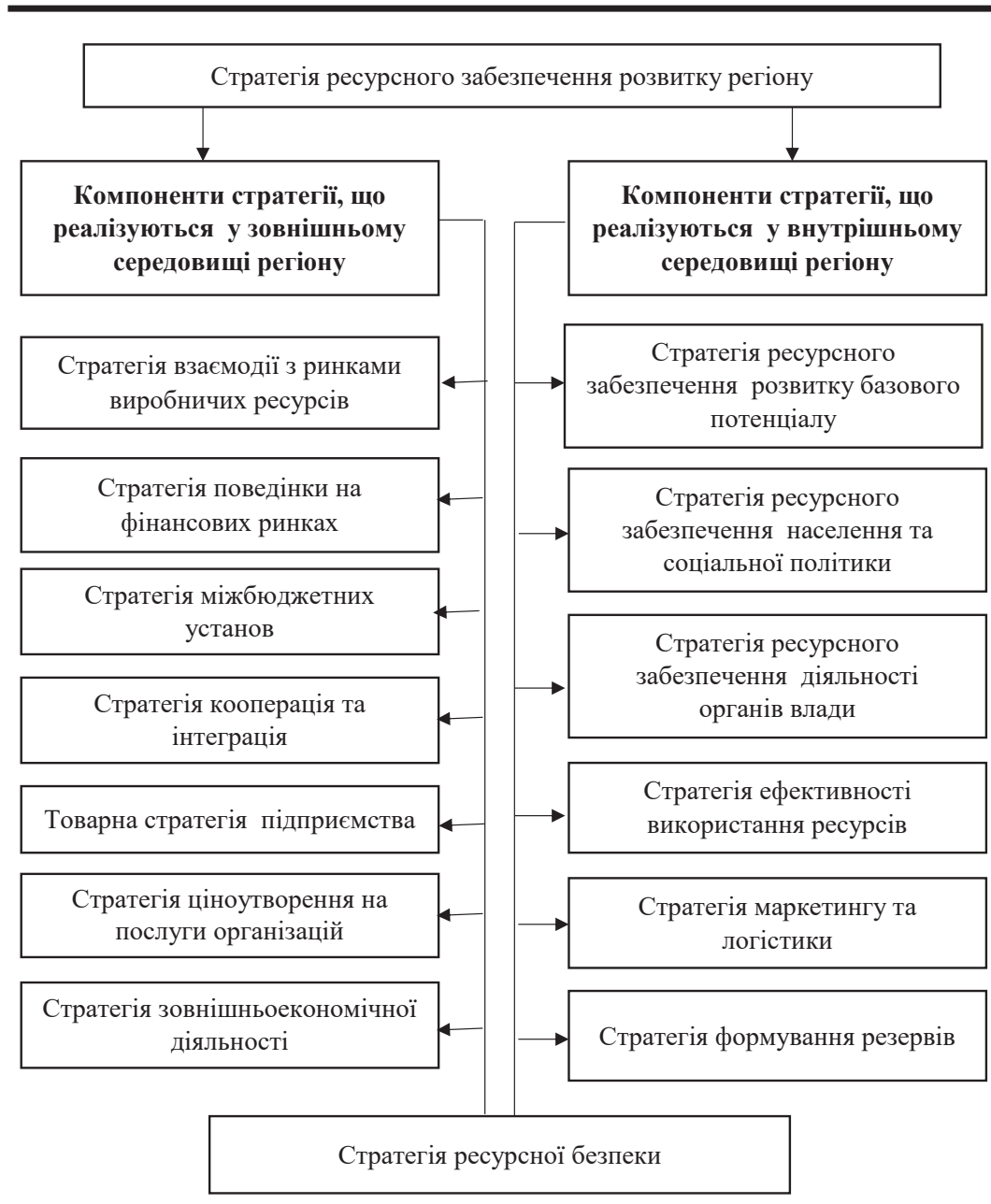

Рис. 1 Стратегія ресурсного забезпечення сталого розвитку регіону ченням потенціалів розвитку, передкризовим або кризовим станом окремих сфер економіки, модернізацією місцевого самоврядування, передбачає вибір стратегії «виживання» і стратегії адаптації економічних агентів до змін у внутрішньому і зовнішньому середовищі. В результаті останньої повинен модифікуватися «генетичний код» регіональної системи - накопичені або надбані нові якісні особливості: ознаки, властивості, здібності, характеристики, що створюють умови для формування повноцінної системи ресурсного забезпечення.

Стратегія ресурсного забезпечення розвитку регіону, що базується на самовідтворенні ресурсів, передбачає активні дії в наступних напрямках: структурна перебудова економіки регіонів і подолання ії монопрофільності; вдосконалення галузевого розвитку економіки регіонів; модернізація організацій інфраструктури регіонів; підтримка малого бізнесу; реформування споживчого ринку та сфери громадського харчування; розвиток інформаційно-комунікаційних технологій; реалізація регулюючої та стимулюючої функції бюджетно-фінансової політики; підвищення інвестиційного потенціалу регіональної системи; оптимізація територіального розвитку районів і створення умов для вирівнювання рівня розвитку економічних агентів н територій регіону. У ситуації, що склалася, необхідно проведення активних заходів з боку місцевої влади і підприємницької спільноти,які сприяють трансформації структури економіки регіонів і змінюють якісний бік економічної динаміки, основними 3 яких є [3]:

- створення інтелектуальних, інноваційних та інституційних змін в економіці територій, здатних надати господарській системі внутрішню енергію ефективного зростання і дозволяють забезпечити перехід до нового якісного стану і до нових пропорцій регіональної системи;

- розвиток старих і нових потенційно конкурентоспроможних виробництв з глибоким ступенем переробки, таких як виробництво з місцевої сировини екологічно чистої продукції, що включає переробку сільськогосподарської продукції, меду, лікарських трав і дарів лісу, виробництво будівельних матеріалів, переробку деревини, розвиток швейного та шкіряного виробництва;

- істотне підвищення випуску і реалізації продукції, ефективності виробництва в переробній промисловості регіону за рахунок зростання продуктивності праці і збільшення доданої вартості, зниження собівартості матеріальних витрат виробництва продукції і послуг, впровадження ресурсозберігаючих технологій;

- формування системи маркетингу, розробка і впровадження єдиної, торгової марки для товарів і послуг, вироблених підприємствами регіону.

- розвиток середовища підприємницького взаємодії, прискорення кооперування та інтеграції приватних товаровиробників в сфері виробництва і переробки продукції, розвитку систем управління якістю продукції, логістики, транспортування вантажів, інформатики, зв'язку, агросервісу, взаємного кредитування;

- формування ефективного приватного та регіонального власника.

Необхідно підкреслити, що в даний час реалізація стратегії ресурсного забезпечення сталого розвитку регіонів країни значно ускладнена в зв'язку з недостатністю фінансових ресурсів. Тому для реалізації стратегії ресурсного забезпечення сталого розвитку регіону важливим $є$ створення певних організаційних умов, виходячи з таких базових передумов:

1. Стратегічний план повинен реально використовуватися як один 3 нормативних документів управління системи ресурсного забезпечення;

2. Завдання ресурсного забезпечення сталого розвитку повинні стати пріоритетними для органів місцевого самоврядування та менеджменту економічних агентів території; 
3. У процесі виконання стратегії має брати участь всі суб'єкти регіону і місцеве співтовариство;

4. Необхідно регулярне інформування всіх зацікавлених сторін про реалізацію планів і проектів розвитку регіональної системи та іï ресурсного забезпечення, обговорення виникаючих проблем.

5. Для здійснення оперативної роботи з реалізації та коригування стратегії ресурсного забезпечення розвитку території в регіоні повинна бути створена група оперативного супроводу стратегічного плану.

Висновок. Таким чином, формування та реалізація стратегії ресурсного забезпечення передбачає розвиток стратегічного управління, яке повинно забезпечувати тривалу життєздатність регіону. Можна визначити два основні кінцеві продукти стратегічного управління:

по-перше, розвиток майбутніх потенціалів регіональної системи, які забезпечують досягнення стратегічних цілей в довгостроковій перспективі;

по-друге, створення адекватної внутрішньої структури i організаційних змін, що забезпечують чут- ливість системи ресурсного забезпечення до змін у зовнішньому середовищі.

В даний час виділяють два напрямки розвитку стратегічного управління. Перше, по суті, це управління стратегічними можливостями регіону, яке $\epsilon$ логічним розвитком стратегічного планування і складається 3 двох взаємодоповнюючих підсистем: підсистеми аналізу та планування стратегії i підсистеми ㄲï реалізації. Друге пов'язане 3 рішенням несподівано виникаючих стратегічних завдань, питаннями адаптації регіональної системи та стратегії її розвитку до постійно змінюваних умов життєдіяльності.

Отже, вдосконалення, системи ресурсного забезпечення сталого розвитку регіону має на увазі використання механізму стратегічного управління на регіональному рівні, включаючи стратегічне планування. Реалізація стратегії можлива на основі використання сучасних технологій управління регіональною системою ресурсного забезпечення.

\section{Список літератури:}

1. Безверхнюк Т. Ресурсний режим як інституційний механізм ресурсного забез- печення регіонального управління. Державне будівництво: електрон. наук. фах. вид. ХарРІ НАДУ, 2010. № 1. URL: http://www.kbuapa.kharkov.ua (дата звернення 13.10.2019)

2. Гончаренко М. В. Теоретичні засади сталого розвитку територій. Теорія та практика державного управління : зб. наук. пр. 2014, Вип. 1 (44), URL: http://www.kbuapa.kharkov.ua/e-book/tpdu/2014-1/doc/3/02.pdf (дата звернення 21.09.2019)

3. Ресурсне забезпечення системи регіонального управління: наук. розробка / М. М. Іжа, Т. А. Берегой, С. А. Попов та ін. К. : НАДУ. 2014. 52 с.

4. Томпсон, Л.Л. Стрикленд, А. Дж. Стратегический менеджмент. Искусство разработки и реализации стратегии: Учебник для вузов. Банки и биржи. ЮНИТИ, 1998. 576 с.

\section{References:}

1. Bezverniuk T. (2010) Resursnyj rezhym jak instytucijnyj mehanizm resursnogo zabezpechennja regional'nogo upravlinnja [Resource regime as an institutional mechanism of regional government resource provision] State building: electron. of sciences. profession. view. HARRY NAD. Available at: http://www.kbuapa.kharkov.ua (accessed 13.10.2019)

2. Goncharenko M.V. (2014) Teoretychni zasady stalogo rozvytku terytorij [Theoretical principles of sustainable development of territories] The theory and practice of public administration: Coll. of sciences, 1 (44). Available at: http://www.kbuapa.kharkov.ua/e-book/tpdu/2014-1/doc/3/02.pdf (accessed 21.09.2019)

3. Izha M.M., Beregoy T.A., Popov S.A. (2014) Resursne zabezpechennja systemy regional'nogo upravlinnja: nauk. rozrobka [Resource Support for the Regional Management System: Sciences. Development]. K.: NADU (in Ukrainian)

4. Thompson L.L. Strickland A.J. (1998) Strategicheskij menedzhment. Iskusstvo razrabotki i realizacii strategii: Uchebnik dlja vuzov [Strategic management. The art of developing and implementing strategies: Textbook for universities]. M.: Banks and exchanges. UNITY (in Russian) 


\section{СТРАТЕГИЯ РЕСУРСНОГО ОБЕСПЕЧЕНИЯ УСТОЙЧИВОГО РАЗВИТИЯ РЕГИОНА}

Достижения устойчивости и комплексности предполагает совершенствование системы ресурсного обеспечения развития территории на основе стратегического планирования, использование современных технологий управления региональной системой ресурсного обеспечения, внедрение системь ее эффективности. В статье определено содержание стратегии ресурсного обеспечения, включаютий несколько элементов, ориентированных на внешнюю и внутреннюю сферы жизнедеятельности на региональном уровне; сформулированы задачи и принщипы стратегического планирования ресурсного обеспечения; определен ичикл его формирования и реализации. Сформулированы основные направления стратегии ресурсного обеспечения, основанной на самовоспроизводство ресурсов и предполагает активные действия по саморазвитию экономики и организационно-экономических отношений в регионах. Охарактеризована стратегия ресурсного обеспечения устойчивого развития региона, которая содержит самостоятельные ресурсные компоненты, реализованные в его внешней и внутренней среде.

Ключевые слова: регион, устойчивое развитие, ресурсное обеспечение, стратегия, стратегическое управление.

\section{STRATEGY FOR RESOURCE PROVIDING SUSTAINABLE DEVELOPMENT OF THE REGION}

Understanding the essence and necessity of managing the formation and functioning of the system of resource support for the development of the region is becoming increasingly important for the authorities, since it allows to consistently implement the main strategic task - improving the level and quality of life of the population. population. Currently, the most progressive is the transition to a model of integrated development, based on the concept of sustainable development, which provides for the functioning of regions as a certain integrity, a complex of harmoniously developed interconnected and complementary territories and industries that provide everyone with decent living conditions, regardless of place of residence and wor. The study and use of world experience in Ukrainian conditions requires the development of a modern model for managing the sustainable development resource system in a market environment operating at the level of specific territories, economic agents and the local community, as well as the region and state. Achieving sustainability and complexity involves improving the system of resource support for the development of the territory on the basis of strategic planning, using modern technologies for managing the regional system of resource support, and introducing a system of its effectiveness. The article defines the content of the resource strategy, which includes several elements focused on the external and internal spheres of life at the regional level; objectives and principles of strategic resource planning are formulated; The cycle of its formation and implementation is defined. The main directions of the resource support strategy are formulated, based on the self-reproduction of resources and providing for active actions for the self-development of the economy and organizational and economic relations in the regions. The resource strategy of sustainable development of the region is described, which contains independent resource components implemented in the external and internal environment. The implementation of the strategy is possible on the basis of the use of modern technologies of management of the regional resource system.

Key words: region, sustainable development, resources, strategy, strategic management. 